\section{Prinsipielt om kreftkirurgi med praktisk slagside}

Silberman H, Silberman AW, red. Principles and practice of surgical oncology Multidisciplinary approach to difficult problems. 1083 s, tab, ill. Philadelphia, PA: Lippincott Williams \& Wilkins, 2009. Pris USD 225 ISBN 978-0-7817-6546-6

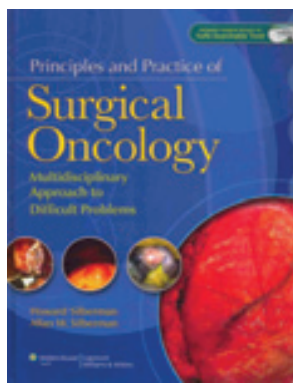

Målgruppen er kirurger som driver kreftkirurgi. Hovedvekten er lagt på multidisiplinær behandling og kompliserte problemstillinger. Tematisk dekkes nær sagt alle organsystemer,

med unntak av sentralnervesystemet. Fordelingen av de 59 kapitlene er noe usystematisk. Boken starter med flere generelle kapitler som tar leseren gjennom genetikk, patogenese og radiologisk diagnostikk, inkludert positronemisjonstomografi (PET). Det virker tilfeldig at kapittel 3 om ernæring hos kreftpasienter er klemt inn mellom temaer som «genetics» og «occult metastasis», mens kapitlet om smertebehandling dukker opp til slutt. Vektingen av tematikken er skjev, med totalt åtte kapitler om brystkreft, mens det til sammenlikning kun er ovarialcancer som omtales av gynekologiske kreftformer. Videre er urologisk cancer gruppert i ett kapittel som dekker nyre, urinblære, prostata og testis. Øvrige svulster har stort sett ett kapittel om kirurgi og ett om adjuvant/medikamentell behandling. Egne kapitler er tilegnet nevroendokrine svulster, gastrointestinal stromal tumor (GIST) samt andre sjeldne tumorer som bløtdelssarkomer og skjelettsvulster.

Spesielle temaer som bekkeneksenterasjon, intraperitoneal kjemoterapi, kirurgisk behandling for peritoneal malign sykdom, bruk av hematopoetisk stamcelletransplantasjon for solide svulster og organtransplantasjon ved kreft dekkes i egne kapitler. Palliasjon som tema er ikke nevnt, verken som eget kapittel eller under andre svulster i nevneverdig grad.

Hvert kapittel er rikt referert, med opptil 250 referanser, men med enkelte unntak er det ikke gjort noe forsøk på å gradere informasjonen. Hvert kapittel er etterfulgt av en kommentar, der forfatteren ofte er svært enig med kapittelforfatteren og der lite ny informasjon eller tilleggsverdi tilfaller leseren.

Boken er trykt på solid papir og inneholder en rekke tabeller, figurer og fotografier, men flere er i dårlig kvalitet eller gjengitt i gråtoner. Enkelte av illustrasjonene er å gjenfinne som fargebilder i et åttesiders addendum, men dette gjelder kun for et lite knippe. Det trekker ned totalinntrykket.
Selv om forfatterne har satt sammen en solid bok, er det flere svakheter ved fremstilling og gjennomførelse som trekker ned. Om man ikke har særinteresse for brystkreft, kan den drøye tusenlappen som boken koster brukes mer fornuftig.

\section{Kjetil Søreide}

Kirurgisk avdeling

Stavanger universitetssjukehus

\section{Ferdskriver på operasjonsstuen}

Flin R, Mitchell L, red. Safer surgery

Analysing behaviour in the operating theatre 456 s, tab, ill. Farnham: Ashgate, 2009.

Pris GBP 75

ISBN 978-0-7546-7536-5

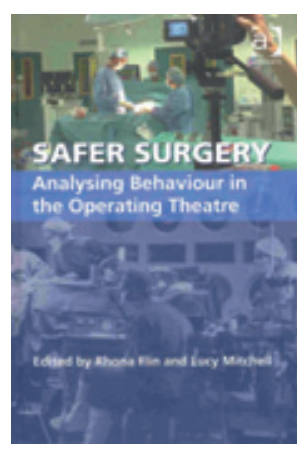

Alle kjenner den magiske «sorte boksen» (black box), eller ferdskriveren, som omtales ved flystyrt og større flyulykker. Ferdskriveren er et apparat som brukes i fly for automatisk og kontinuerlig å registrere data

som kan bidra til å klarlegge årsakssammenhengen ved f.eks et havari. I tillegg til registrering av utallige tekniske data, er det gjerne opptak av samtaler mellom pilotene og besetningen som kan belyse atferd i cockpiten som er av interesse forut før en hendelse. Ressursene som settes inn $\mathrm{i}$ å finne de sorte boksene, som etter Air France-ulykken i juni 2009, belyser hvor viktig denne informasjonen er for å forstå en ulykke. Kan «ferdskrivere» på operasjonsstuen gjøre samme nytten?

Operasjonsstuene er en lukket og intim sfære hvor mye informasjon og kommunikasjon kan være uforståelig for den utenforstående. I denne boken presenteres atferdsforskning på operasjonsstuen. Her beskrives teknikker og metoder som kan brukes for å undersøke og analysere atferd $i$ dette arbeidsmiljøet, og det gis en oversikt over hvilken betydning dette kan ha for sikkerheten ved kirurgiske inngrep. Målgruppen er tverrfaglig, og alle som er på en operasjonsstue - kirurger, anestesileger, sykepleiere og annet personell. Tilnærmingen er hovedsakelig fra et sosialvitenskapelig perspektiv. Begge redaktørene er psykologer i bunn, og langt de fleste kapitlene har en atferds- og psykologivitenskapelig innfallsvinkel. Hele boken har atferd og kommunikasjon på operasjonsstuen som et gjennomgående tema, men er ikke utelukkende skrevet av psykologer, flere kapitler er skrevet av kirurger, anestesileger, barneleger, eller andre profesjoner, som sykepleiere og, kanskje forståelig nok, flypiloter. Felles er tilnærmingene for å forstå hvordan mennesker fungerer $i$ team, og fra ulike profesjoner, og i hvilken grad dette har innflytelse på pasientbehandling og -sikkerhet.

Boken er kommet i stand som et resultat av et forskningssymposium avholdt i Aberdeen i 2007, med deltakere fra California til Karolinska, og fra Aberdeen til Zürich. Som et møtereferat følger det at en del kunnskap er noe prematurt presentert, spesielt i midterste delen av boken som omhandler ulike pågående, planlagte eller ikke ferdig analyserte studier. I de første ti kapitlene omtales diverse metoder for å vurdere og analysere atferd på operasjonsstuen, bl.a. hos kirurger gjennom NOTSS (Non-Operative Technical Skills for Surgeons) og hos operasjonssykepleier gjennom SPLINTS (Scrub Practitioners' List of Intra-Operative Non-Technical Skills). Nettopp bruk av akronymer er noe som går igjen i stor grad, og som til dels fremmedgjør innholdet $\mathrm{i}$ kapitlene. Videre er det en rekke figurer og lange tabeller som beskriver definisjoner brukt i ulike verktøy, og en god del av disse er veldig omfattende og tunge. Blant det som må betegnes som veldig fagspesifikke kapitler, er det en god del «lysglimt» av lettere karakter og som er interessant lesing. Som eksempel kan nevnes et kapittel om «stillhet» som kommunikasjon - og hvordan man kan analysere dette (for det kan man visst!). Det gis eksempler på kommunikasjon, verbal og ikke-verbal, som er treffende. Videre følger kapitler om bl.a. "surgical decisionmaking», simulatortrening og påvirkende faktorer som tidspress, eksterne forstyrrelser under operasjoner og ulike modeller for å vurdere dette. En stor andel av kapitlene har en teoretisk-vitenskapelig tilnærming som gjør at man må være over gjennomsnittlig interessert for å henge med andre avsnitt er mer matnyttige og interessante.

Boken er solid innbundet og trykt på godt papir. Innholdet fanger vidt over et viktig tema. Som en introduksjon til området atferd og kommunikasjon på operasjonsstuen er den relativt tung, men inneholder noe for de fleste fagdisipliner, og man kan velge bort de mest teoretiske vinklingene. Til tross for enkelte svakheter, den tar opp et høyst aktuelt temaområde for alle involverte på operasjonsstuen.

Kjetil Søreide

Kirurgisk avdeling

Stavanger universitetssjukehus 